\title{
O LUCRO DE ALGUNS COM DEGRADAÇÃO AMBIENTAL É PREJUÍZO DE TODOS
}

O final do ano de 2008 encerrou com notícias positivas para a Química e a ciência brasileira e incertezas para todos.

A queda vertiginosa do crescimento da economia mundial afetará a produtividade do mundo e a competição entre as economias pressionará salários para baixo, haverá diminuição do consumo e dos investimentos e, consequentemente, desaceleração do crescimento econômico. O pânico tomou conta das empresas que começam a demitir em massa. As indústrias químicas não estão isentas deste turbilhão mundial e como têm um peso significativo no PIB brasileiro, com certeza também serão bem afetadas. Apesar das notícias afirmarem que a crise financeira vem de fora, cada um dos muitos afetados por ela sente bem o seu peso no dia-a-dia.

Por outro lado, os Institutos Nacionais de Ciência e Tecnologia (os INCTs) disponibilizarão, aos melhores grupos de pesquisa em áreas de fronteira da ciência, recursos da ordem de R\$ 600 milhões. Além de agregar os pesquisadores mais produtivos em temas relevantes para a ciência, o programa INCT conseguiu reunir as agências de fomento CNPq, BNDES, FAPs, CAPES, FINEP e empresas, como a Petrobras. Tudo isso de forma articulada nas áreas estratégicas para o desenvolvimento do país. O Prof. Jailson B. Andrade, editor do Journal of the Brazilian Chemical Society, utilizou um termo bem químico para definir este empreendimento: "Trata-se da maior ação concertada de investimentos em Ciência, Tecnologia e Inovação envolvendo uma grande rede, descentralizada, com sedes em todas as regiões do país. O futuro chegou!'”.

Outro ponto positivo que gostaríamos de ressaltar, foi a escolha do ano de 2011 como o Ano Internacional da Química pela a $63^{\text {a }}$ Assembléia Geral das Nações Unidas (ONU), realizada em 30 de dezembro de 2008. A proposta foi encaminhada pela IUPAC à ONU pela delegação da Etiópia com a subinscrição de 35 países. As comemorações serão coordenadas pela IUPAC e UNESCO. A escolha deste ano não foi ao acaso, pois se trata do $100^{\circ}$ aniversário do Prêmio Nobel em Química para Marie Sklodowska Curie (1867-1934).

Desta ação da ONU desprendem-se duas considerações importantes: os reconhecimentos das contribuições das mulheres para a Ciência e da Química para o bem-estar da humanidade.

Marie Sklodowska Curie recebeu da Real Academia Sueca de Ciências dois Prêmios Nobel. O primeiro foi agraciado em Física em 1903, junto Pierre Curie e Henri Becquerel, pelos estudos dos fenômenos de radiação, descobertos por Becquerel. Este foi o primeiro Prêmio Nobel concedido a uma mulher, mostrando que a ciência não era uma atividade exclusiva dos homens. Oito anos mais tarde, em 1911, recebeu o segundo Nobel, desta vez em Química, pela descoberta dos elementos Rádio e Polônio e sobre a natureza dos seus compostos. Foi a primeira pessoa a receber dois Prêmios Nobel em campos diferentes. Entretanto, neste mesmo ano a Academia de Ciências de Paris rejeitou sua admissão, por apenas um voto. Ainda estava muito longe, e permanece assim até hoje, das mulheres participarem dos centros e núcleos de decisões, dos escalões superiores na ciência, ${ }^{2}$ apesar ser bem conhecido que em muitas áreas científicas o aumento de produtividade foi devido às suas importantes contribuições. Os tempos mudam e cada vez mais as mulheres ocupam cargos antes só ocupados pelos homens, como é o caso da Sociedade Brasileira de Química, que na sua breve história pode se orgulhar de ter uma mulher presidente.

A proclamação deste ano Internacional da Química traz uma responsabilidade enorme para a Química praticada no mundo. Uma parte minoritária da população sabe que a Química é responsável por produtos que envolvem a produção de alimentos, medicamentos, combustíveis e inúmeros materiais manufaturados utilizados no cotidiano. Porém, a percepção de uma grande maioria é que a Química está envolvida em todos os tipos de agentes poluidores e devastadores do meio ambiente, nos explosivos, nas guerras químicas, nos agrotóxicos, ou seja, em todos os malefícios da humanidade. Portanto, estas comemorações devem ser aproveitadas para aumentar a visibilidade e sensibilidade do público sobre os seus aspectos positivos e que ela pode vencer os desafios de um desenvolvimento sustentável. Os paradigmas atuais e importantes para a humanidade são as futuras fontes de energia e a produção de alimentos para a crescente população do mundo. A Química está no centro destes dois paradigmas.

As empresas químicas fazem parte do conjunto da sociedade que tem como objetivo primordial promover o bem-estar, criando soluções para os problemas que ainda não foram resolvidos e devem estar inseridos num contexto de desenvolvimento socioeconômico sustentável. É real e urgente a necessidade de processos mais limpos que utilizem novas fontes energéticas e reagentes mais baratos, menos tóxicos, com diminuição da quantidade de rejeitos gerados, mesmo que em algumas situações os processos que geram menos resíduos sejam mais caros. As políticas industriais devem estar em consonância com as questões ambientais.

A concepção de uma Química limpa e ambientalmente mais recomendável passa necessariamente pela vontade política dos países que devem associar os aspectos econômicos com educação ambiental de qualidade, substituição de combustíveis fósseis e de processos químicos ultrapassados. Porém, o mais importante de uma política industrial é que ela perceba que o lucro de alguns com degradação ambiental é prejuízo de todos.

\section{Suzana I. Córdoba de Torresi Vera L. Pardini Vitor F. Ferreira Editores de QN}

\section{REFERÊNCIAS}

1. de Andrade, J. B.; J. Braz. Chem. Soc. 2009, 20, iii.

2. da Costa, M. C.; Cad. Pagu no 27 Campinas July/Dec. 2006 (doi: 10.1590/S0104-83332006000200018). 